\title{
Gene networks in the embryo and endometrium related to embryo survival
}

\author{
Michael Hoelker, Dessi Salilew-Wondim, Eva Held, Dawit Tesfaye \\ and Karl Schellander \\ Institute of Animal Science, Animal Breeding and Husbandry Group, University of Bonn, \\ Bonn, Germany
}

\begin{abstract}
Summary
Low fertility is one of the major problems limiting the efficiency of the dairy industry. Successful pregnancy establishment and development to term depend on the suitability of the endometrial environment and the intrinsic quality of the embryo. Accurate assessment of both, however, is challenging. Therefore, the present survey reviews current knowledge of the molecular networks in the endometrium related to pregnancy establishment and maintenance to term. Accordingly, distinct molecular signatures of the bovine endometrium, elucidated by innovative approaches, could be correlated with pregnancy success. However, not only must the reproductive tract provide a suitable environment but the embryo itself must be competent to express its developmental program. Numerous studies have correlated molecular networks of bovine embryos with their developmental capacity. However, most studies were, by their nature, invasive and the findings were therefore difficult to extrapolate beyond the developmental stages examined. Hence, a second aim is to present new strategies employing embryo biopsies for a direct connection between molecular signatures and embryo developmental capacity. Large scale differences, at the molecular level, were reported for blastomeres whose counterparts developed to the blastocyst stage compared to those with lower developmental competence, thus unraveling distinct molecular fingerprints related to ability to develop to the blastocyst stage. Similarly, distinct molecular signatures at the blastocyst stage were associated with embryo developmental competence to term. In summary, further understanding of molecular signatures related to endometrial receptivity and embryo developmental capacity has been gained from novel innovative strategies including embryo microdissection as well as by examining endometrial samples collected in the cycle preceding the one in which conception occurs.
\end{abstract}

\section{Introduction}

Low fertility is one of the major problems limiting the efficiency of the dairy industry with the majority of embryonic losses occurring between days 8 and 16 after mating (Diskin \& Sreenan 1980, Diskin et al. 2006). In the bovine, fertility is dependent upon the following: 1) the ability of a cow to cycle and 2) development of appropriate endocrine conditions within the reproductive tract to ensure a healthy and receptive environment capable of supporting embryonic/fetal development culminating in a viable offspring. Imbalance of embryo-maternal communication is believed to be a major cause of pregnancy failure in large part as a consequence of molecular dysregulation (Glencross et al. 1973, Tabibzadeh \& Babaknia 1995, Spencer et al. 1996, 
Tabibzadeh 1998, Paria et al. 2000, Paria et al. 2001, Paria et al. 2002, Riesewijk et al. 2003, Dey et al. 2004, Giudice 2004, Bauersachs et al. 2006, Wang \& Dey 2006, Spencer et al. 2007, Spencer et al. 2008, Bauersachs et al. 2009, Boomsma et al. 2009). Thus, there is a large amount of evidence that the properties of the maternal environment are major determinants of pregnancy establishment and maintenance. Predictive criteria to classify the suitability of a given endometrial environment, however, remain elusive.

Additionally, the embryo must be competent to successfully undergo preimplantation development, elongation, implantation and term development. Embryo quality is related to the embryo's intrinsic properties and environmental consequences established by the dam or during assisted reproductive techniques. Indeed, in vitro produced bovine embryos remain inferior in terms of viability compared to embryos developed in vivo (Farin \& Farin 1995, Numabe et al. 2000). Likewise, various studies have shown that bovine embryo production under specific culture conditions resulted in not only an altered embryonic and foetal development following transfer, but also altered gene expression of transcripts related to metabolism and growth (Khosla et al. 2001, Lazzari et al. 2002). Consequently, deviant expression of developmentally important genes has been implicated as a causative factor of embryonic death during preimplantation development (Lonergan et al. 2006) and several studies have reported candidate genes related to developmental competence (Lonergan et al. 1999, Brevini et al. 2002, Rief et al. 2002, Knijn et al. 2005, Dode et al. 2006, Corcoran et al. 2007). Direct connections between embryonic gene expression profiles and subsequent developmental capacity, however, remain elusive and the underlying molecular mechanisms regulating developmental competence are unknown.

Consequently, this review summarizes knowledge with respect to endometrial networks affecting bovine receptivity taking into account direct relationships between endometrial gene expression profiles and later pregnancy success. Secondly, this review focuses on embryonic molecular signatures related to embryo developmental competence and novel strategies which enable concomitant assessment of molecular signatures and developmental competence of individual bovine embryos.

\section{Endometrial gene networks for embryo survival}

While the oviduct is the critical environment for fertilization, initial embryo development and transport of the embryo into the uterus (Austin 1951, Austin 1952, Fazeli et al. 2004), the uterus hosts the bovine embryo from days 4-5 of development to parturition. Consequently, the embryoendometrial dialogue requires several endogenous molecules produced in the endometrium and/or the embryo (Glencross et al. 1973, Tabibzadeh \& Babaknia 1995, Spencer et al. 1996, Tabibzadeh 1998, Paria et al. 2000, Paria et al. 2001, Paria et al. 2002, Riesewijk et al. 2003, Dey et al. 2004, Giudice 2004, Bauersachs et al. 2006, Wang \& Dey 2006, Spencer et al. 2007, Spencer et al. 2008, Bauersachs et al. 2009, Boomsma et al. 2009). Among these molecules are adhesion molecules, namely integrins, cadherins, and selectins (Lessey 1997, Tabibzadeh 1998), cytokines (Salamonsen et al. 2000, Achache \& Revel 2006, Ledee et al. 2007), growth factors/ growth factor receptors (Cross et al. 1994, Carson et al. 2000, Norwitz et al. 2001, Paria et al. 2001, Lim et al. 2002) as well as chemokines (Salamonsen et al. 2007). Integrins, for example, are involved in cell-cell and cell-substrate interactions (Albelda \& Buck 1990) and appropriate endometrial expression is necessary for receptivity in humans (Lessey 1997). Among the cytokine family the importance of LIF for embryo implantation in different species has been reported (Stewart et al. 1992, Chen et al. 1995, Danielsson et al. 1997, Salamonsen et al. 2000, Song et al. 2000, Lim et al. 2002, Li et al. 2010). In addition to cytokines, the important role of growth factors and their receptors has been reported for embryo growth and uterine receptivity 
in several studies (Cross et al. 1994, Carson et al. 2000, Norwitz et al. 2001, Paria et al. 2001, Lim et al. 2002). In particular, hepatocyte growth factor (HGF), macrophage colony stimulating factor (MCSF), colony stimulating factor 1 (CSF1), insulin-like growth factors (IGF1 and IGF2) and especially granulocyte-macrophage colony stimulating factor (GMCSF) have been reported to affect conceptus survival (Kauma 2000, Salamonsen et al. 2000, Ledee et al. 2007).

Pregnancy maintenance is under the control of progesterone (Savouret et al. 1990) with inadequate circulating concentrations of progesterone causing pregnancy failure (Ghosh \& Sengupta 2004, Lonergan 2011). Whereas a delayed progesterone increase after ovulation is associated with lower conception rate in cattle (Henricks et al. 1971), low concentrations of progesterone caused by inadequate luteal function are associated with reduced embryo development (Rizos et al. 2010). Alternatively, progesterone supplementation before embryo transfer is discussed to speed up blastocyst formation, blastocyst expansion (Ferguson et al. 2011) and promotes conceptus elongation (Garrett et al. 1988, Geisert et al. 1991, de Ziegler et al. 1998 ). Overall, it is generally accepted that these effects of progesterone are mediated through nuclear receptors, which in turn alter the endometrial gene expression profile (Suzuki et al. 2008). Indeed, addition of exogenous progesterone resulted in altered endometrial expression of fatty acid binding protein (FABP), diacylglycerol O-acyltransferase 2 (DGAT2), myostatin (MSTN), crystalline gamma $S$ (CRYGS) and other genes in the bovine (Forde et al. 2009a, Forde et al. 2009b). Furthermore, progesterone treatment was found to affect the expression of genes involved in endometrial WNT signaling (Satterfield et al. 2008), the expression of fibroblast growth factor 7 (FGF7), fibroblast growth factor 10 (GF10), insulin like growth factor binding proteins (IGFBP1, $-3,-4)$, hepatocyte growth factor $(H G F)$ and others in sheep endometrial epithelia (Spencer \& Bazer 2002). Thus, progesterone affected the expression of endometrial genes as well as uterine receptivity in parallel.

\section{Endometrial gene expression as a molecular cue for pregnancy establishment}

Aberrant endometrial gene expression during the critical period of pregnancy establishment was correlated with implantation failure and infertility (Tabibzadeh \& Babaknia 1995, Tapia et al. 2008). Thus, selection of recipients based on endometrial gene expression pattern might be useful for predicting subsequent endometrial receptivity before transferring valuable bovine embryos. Studies in mice with delayed implantation (Reese et al. 2001) and in ewes in which uterine glands were knocked out (Spencer et al. 1999, Gray et al. 2002) have contributed substantial information about potential markers for uterine receptivity and embryo implantation. The results of these retrospective studies, however, do not address whether pre-conception properties of the endometrium are related to subsequent pregnancy outcome. To fill this gap, we have conducted studies in which endometrial samples were collected by the cytobrush approach at days 3 and 7 (day 0 = day of oestrus) of the cycle preceding the one in which bovine embryos were transferred to recipients (Figure 1). These samples were categorized retrospectively according to pregnancy outcome of the recipients and were analysed with respect to the global transcriptome profile (Salilew-Wondim et al. 2010, Ponsuksili et al. 2012).

Interrelationship between pregnancy success and endometrial gene expression at day 3 of the preceding cycle

It has been shown that recipients of contrasting receptivity differ at day 3 of the preceding cycle with regard to many biological processes and molecular functions (Ponsuksili et al. 


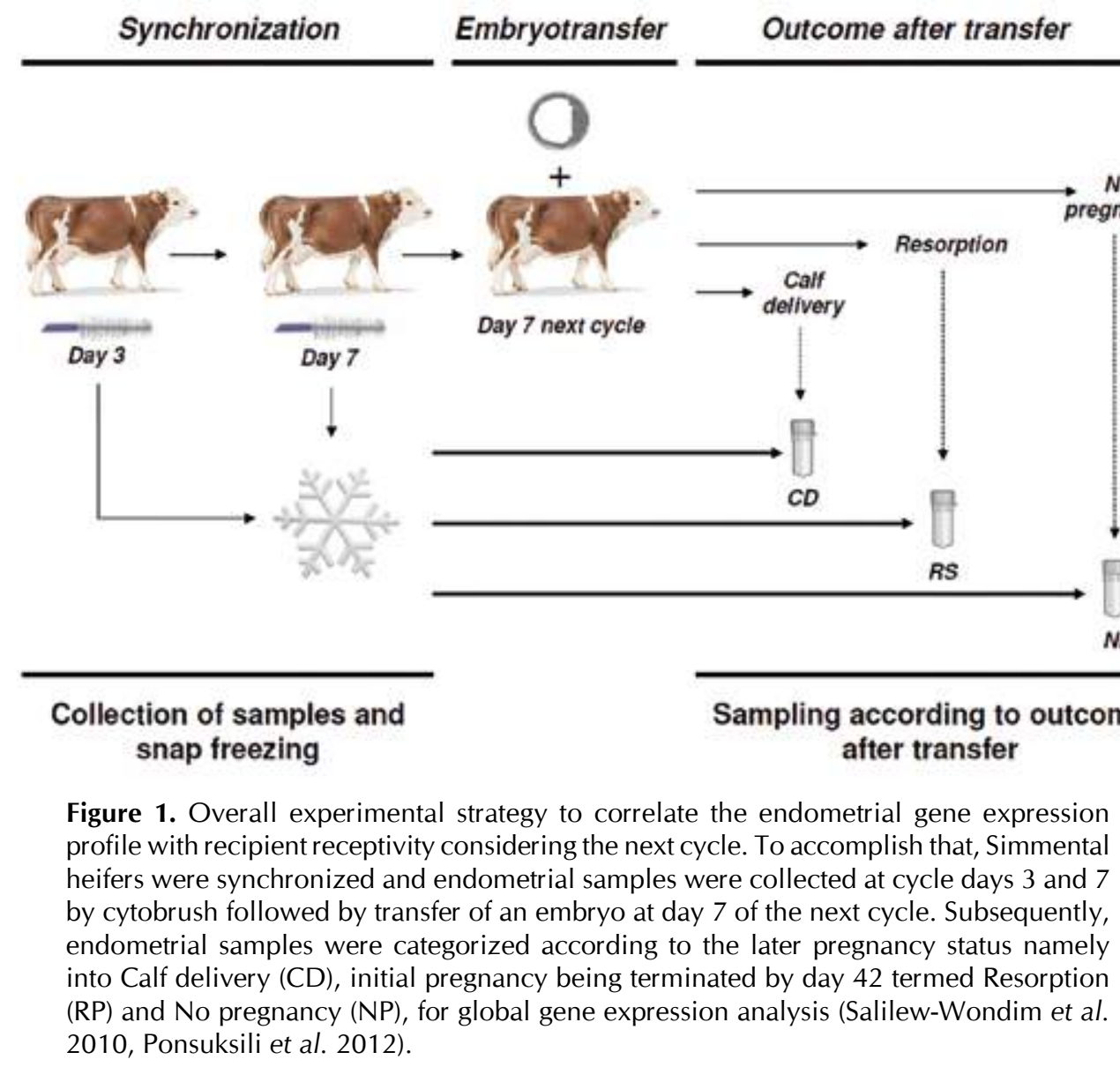

2012). More specifically, molecular signaling pathways in the endometrium were differentially expressed between high and low fertility groups prior to implantation and molecules involved in integrin signaling, cytoskeleton signalling, and Rac signaling were enriched in the receptive endometrium. Previously, transcripts in these pathways were found to increase during the window of implantation and therefore have been proposed as markers for implantation (Aplin 2000, Bowen \& Hunt 2000, Thomas et al. 2003, Revel et al. 2005, Achache \& Revel 2006). Integrins for instance, participate in cell-matrix and cell-cell adhesion in many physiologically important processes and the acquisition of adhesion ligands contributes to endometrial receptivity (Aplin 2000, Bowen \& Hunt 2000). Alternatively, many transcripts that belong to functions relevant to energy supply, including mitochondrial pathways, showed lower abundance at day 3 of the preceding oestrous cycle in cows having a less receptive endometrium (Ponsuksili et al. 2012). This indicates that defects in these pathways may negatively affect uterine receptivity. Interestingly, gene-set enrichment pathway analysis has identified mitochondrial dysfunction as a biological process related to timing of menopause in humans, coinciding with a reduction in circulating oestrogen concentrations (Stolk et al. 2012). Similarily, the observed expression differences related to mitochondrial function were prominent at day 3 post oestrus, when oestrogen was still the dominant ovarian hormone in the bovine. Thus, level of ovarian hormones at day 3 might affect endometrial regulation of mitochondrial biogenesis and activity and, in turn, affect receptivity of the endometrium. 
Interrelationship between pregnancy success and endometrial gene expression at day 7 of the preceding cycle

The results of our studies revealed distinct differences in the endometrial gene expression profile on day 7 of the oestrous cycle between females categorized as having high and low endometrial receptivity to an embryo in the following cycle (Salilew-Wondim et al. 2010, Ponsuksili et al. 2012). Several biological processes including macromolecular localization and protein metabolism were overrepresented in genes elevated in biopsies associated with calf delivery (Figure 2A). In contrast, biological processes like response to stimulus, immune system process, developmental process, cellular metabolic process and regulation of transcription were found to be overrepresented in genes elevated in samples that did not result in a pregnancy (Figure 2B). Moreover, endometrial activation of distinct molecular pathways including tight junction formation, integrin signalling, focal adhesion, apoptosis, cell cycle, peroxisome proliferator activated receptors, GnRH signaling pathway, insulin signaling pathway, inositol phosphate metabolism and glycan biosynthesis was observed in heifers that delivered a calf compared to those that failed to become pregnant (Salilew-Wondim et al. 2010). Likewise, endometrial transcripts of genes of the solute carrier family, protein kinases and phosphatases and transmembrane proteins were found to be more abundant in heifers that resulted in a successful pregnancy. Importantly, genes believed to play a role within the immune system, including a cluster of differentiation molecules and chemokine molecules, were down regulated in endometrial samples correlated with pregnancy establishment and calf delivery (Salilew-Wondim et al. 2010). This is in agreement with our recent study in which several inflammatory and immune mediators playing a role in T- and B cell signalling as well as NF-kB signalling were more highly expressed at day 7 in the receptive endometrium (Ponsuksili et al. 2012). That might indicate that a rather moderate endometrial immune response may be a prerequisite for later embryo implantation. Furthermore, in humans the implantation window is characterized as an inflammatory event associated with increased expression of inflammatory mediators and immune cell infiltration (van Mourik et al. 2009) with extensive alterations of endometrial genes involved in cell-mediated immune response reported to be associated with female infertility (Ledee et al. 2011).

(A)

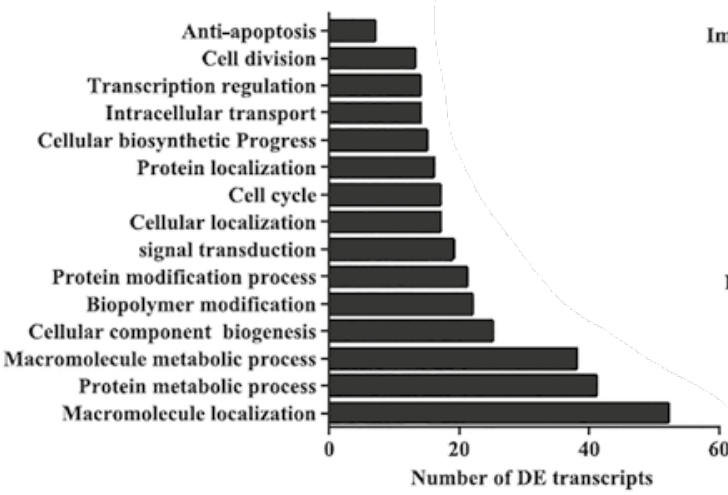

(B)

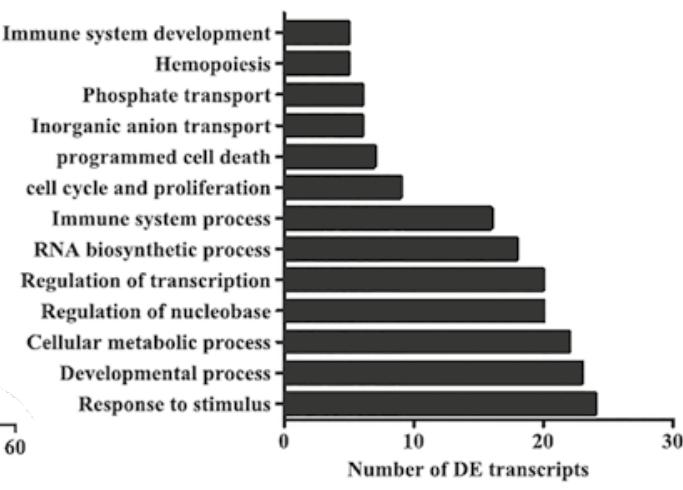

Figure 2. Overrepresentation of gene sets defined by the biological process of Gene Ontology for differential expressed genes whose transcript level was increased in endometrial samples associated with calf delivery (A). Overrepresentation of gene sets defined by the biological process of GO for genes whose transcript level was decreased in endometrial samples associated with calf delivery compared to those that did not result in a pregnancy (B) as published previously (Salilew-Wondim et al. 2010) 
Moreover, samples collected on day 7 of the oestrous cycle, which corresponded with low uterine receptivity, showed an increase in expression of transcripts associated with inhibition of angiogenesis and NRF2-mediated oxidative stress (Ponsuksili et al. 2012). Endometrial angiogenesis, however, has been previously reported to play an important role in implantation and maintenance of pregnancy (Saino et al. 2004)(Sugino et al. 2002). Thus, contrasting expression of genes involved in angiogenesis among the high and low receptive groups might reflect a poor preparation of the endometrium to receive and support an embryo. Correspondingly, higher expression of oxidative stress response genes was found in the low receptive group at day 7 post oestrus (Ponsuksili et al. 2012). With respect to transcripts involved in oxidative stress, however, several lines of evidence indicate that oxidative stress is associated with pregnancy loss or complications of various pathological backgrounds (Liu et al. 2011, Loset et al. 2011).

\section{Embryo gene networks for embryo survival}

In addition to properties of the endometrium, the embryo has to acquire a minimum intrinsic quality to enable elongation, implantation and development to term. Viable bovine embryos, that persist until days 16 and 19 post conception, activate certain genes that are related to implantation and embryo-maternal communication (Mamo et al. 2011). In cattle, the elongated day 14-17 embryo produces interferon-tau (IFNT) capable of binding to endometrial type-I IFN receptors (Li \& Roberts 1994, Naivar et al. 1995, Bazer et al. 1997, Spencer et al. 2008), thereby stimulating the expression of endometrial genes necessary for embryo implantation (Spencer et al. 2008). Embryo development beyond the blastocyst stage and subsequent implantation, however, depends on proper activation of the embryonic genome (Betts \& King 2001); whereas deviant expression of developmentally important genes has been implicated as a causative factor of embryonic death during preimplantation development (Lonergan et al. 2006). Thus the mRNA makeup of the early embryo and/or blastocyst is suggested to reflect an embryo's intrinsic quality and might predict its future developmental capacity.

\section{Molecular signatures presumably associated with embryo developmental competence}

Embryos having different morphologies, contrasting maternal/in vitro environments, different developmental kinetics and different origins (vivo, vitro, nuclear transfer), not only exhibit contrasting degrees of developmental competence, but also display differences with respect to mRNA pattern. Thus, it is reasonable to consider these mRNA patterns as molecular signatures of presumed embryo developmental capacity. Several reviews have summarized relationships between candidate gene expression patterns and embryo quality (Wrenzycki et al. 2005, Lonergan et al. 2006, Wrenzycki et al. 2007, Duranthon et al. 2008). Bearing in mind that in vitro produced bovine embryos are of lower viability compared to in vivo produced embryos (Farin \& Farin 1995, Numabe et al. 2000), qualitative differences in mRNA expression of connexin 43 (CX43) and genes from the leukemia inhibitory factor (LIF) family exist between in vivo and in vitro derived bovine blastocysts (Wrenzycki et al. 1996, Eckert \& Niemann 1998). Later, various studies reported aberrations from the normal mRNA pattern for in vitro produced embryos compared to in vivo derived and nuclear transfer derived embryos (Eckert \& Niemann 1998, Wrenzycki et al. 1999, Doherty et al. 2000, Lee et al. 2001, Minami et al. 2001, Wrenzycki et al. 2001, Rief et al. 2002, Rizos et al. 2002a, Rizos et al. 2002b, Rizos et al. 2003, Smith et al. 2005, Kato et al. 2007). However, although the relationship between bovine 
blastocyst quality and gene expression has been the focus of numerous studies (Wrenzycki et al. 2005, Lonergan et al. 2006, Wrenzycki et al. 2007, Duranthon et al. 2008), and these studies indeed provided valuable information about bovine embryonic gene expression, the conclusions that could be drawn from a small number of candidate genes, was rather limited.

Subsequently, cDNA-arrays allowed simultaneous quantification of a set of transcripts, even in single embryos (Brambrink et al. 2002). These cDNA microarrays were used to compare differential expression between in vivo and in vitro derived bovine blastocysts (Corcoran et al. 2007) and between bovine blastocysts that had developed in different culture systems (Hoelker et al. 2009, Cote et al. 2011). Accordingly, we have conducted a study to examine the effect of alternative in vivo and in vitro culture conditions at the time of major embryonic genome activation on developmental rates and transcriptome profiles of bovine blastocysts (Gad et al. 2012). Furthermore, cDNA microarrays have been employed to contrast gene expression in embryos derived from somatic cell nuclear transfer compared to "normal" fertilization (Smith et al. 2005). Interestingly, that study reported that the global transcriptome of clones was more similar to in vitro derived blastocysts than to in vivo derived blastocysts, whereas the global transcriptome was shown to differ largely between ex vivo and nuclear transfer derived elongated bovine embryos (Betsha et al. 2013) as well as in Day 50 placentas (Salilew-Wondim et al. 2013).

Nevertheless, it is still a challenge to interpret differences in global transcriptome profiles between pools of embryos classified according to their presumed developmental competence based on phenotype and/or origin. When considering these group-based findings, however, one has to consider that not all embryos of a given phenotype bear the same viability and individual embryos may respond differently to identical culture conditions (Lequarre et al. 1997, De Sousa et al. 1998, Krussel et al. 1998), which might be a reflection of their intrinsic quality. Hence, although the embryo gene expression blueprint may be indicative of subsequent developmental competence, current approaches based on presumed embryo developmental competence are suboptimal for identifying molecular markers that predict the ability of a blastocyst to establish a pregnancy. Moreover, molecular studies are, by their nature, invasive making it difficult to extrapolate the developmental competence beyond the developmental stages examined. As a consequence, new strategies have been designed to identify molecular networks related to future developmental competence of individual bovine embryos.

\section{Molecular signatures for cleavage stage embryo survival to blastocyst stage}

Recently, a strategy for unravelling molecular signatures indicative of developmental capacity of early bovine embryos to the blastocyst stage, without compromising the embryo's subsequent developmental competence, has been reported by our group (Held et al. 2012). Briefly, separated blastomeres in a two-cell embryo were classified according to their sister blastomere's development (Figure 3) and were analysed for their global gene expression profile. The results of that study revealed that developmental fates of sister blastomeres were highly correlated. Interestingly, other studies had shown that following blastocyst transfer at Day 7, different types of embryos (in vivo-derived, in vitro-derived, nuclear transfer-derived) elicit different responses from the endometrium around the time of initiation of implantation, and these responses are associated with different developmental outcomes (Madaschi et al. 2009, Mansouri-Attia et al. 2009). In other words, each sister blastomere represents one side of the same coin being also master of its own destiny even after isolation. Microarray analysis revealed a total of 632 genes that were differentially regulated between blastomeres, whose sister blastomeres reached the blastocyst stage and those that did not cleave following separation. The primary pathways that differed were related to oxidative phosphorylation and NRF2-mediated stress 


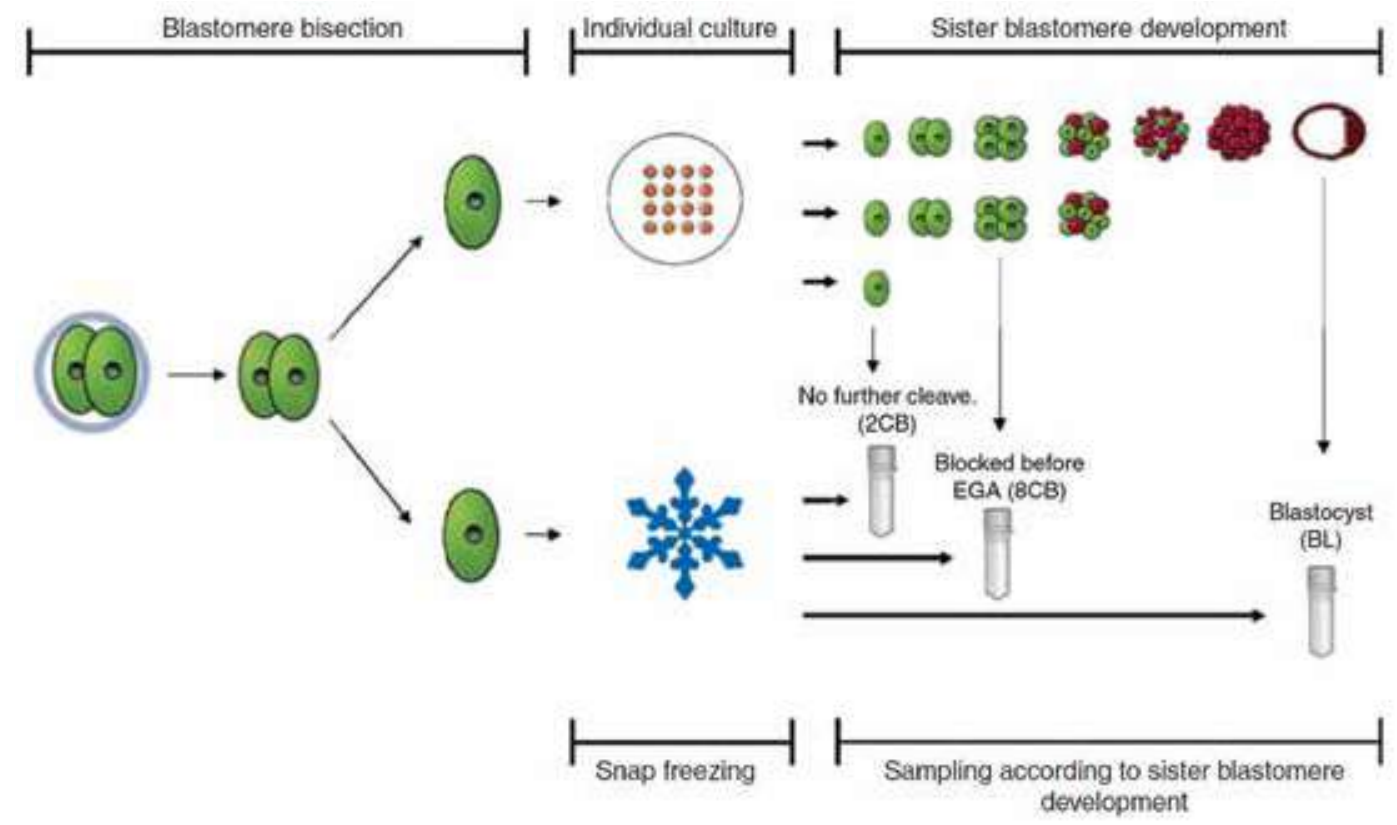

Figure 3: Single blastomeres derived from bisected 2-cell stage embryos were cultured individually, whereas the corresponding sister blastomeres were frozen and stored individually. Frozen stored blastomeres were pooled according to the subsequent development of their corresponding sister blastomeres into three groups: (1) corresponding sister blastomeres that did not cleave anymore after bisection (2-cell block, 2CB); (2) corresponding sister blastomeres that stopped development after two additional rounds of cell cleavage as 4-cell embryos following bisection (8-cell block, 8CB); and (3) corresponding sister blastomeres that developed to the blastocyst (BL) stage (Held et al. 2012; reproduced with permission).

response. Similarly, 150 genes were differentially regulated between samples associated with blastocyst development and those whose sister blastomeres stopped cleaving before embryonic genome activation (Held et al. 2012), with the preceding genes primarily also related to the NRF2-mediated stress response pathway. Collectively, both comparisons showed an overlap of a total of 77 genes. Clustering of these differentially expressed genes according to molecular functions and pathways revealed antioxidant activity, NRF2-mediated oxidative stress response, and oxidative phosphorylation to be the main ontologies affected. Subsequently, expression of selected candidate genes playing a role in oxidative phosphorylation and oxidative stress response (NDUFS1, MAPK14, CAT, PRDX1 and PRDX6) was validated in early and late cleaving two-cell embryos representing an independent model for developmental competence with early cleaving embryos presumed to be of higher developmental competence.

\section{Molecular signatures for blastocyst survival to term}

To correlate molecular signatures at the blastocyst stage with the ability of the embryo to establish a pregnancy, a novel model was established in which a biopsy was taken from a blastocyst, followed by transfer of the biopsied blastocyst to a recipient (El-Sayed et al. 2006). The preceding approach allowed analysis of gene expression profiles of in vitro-produced Day- 
7 blastocyst biopsies based on the pregnancy outcome after transfer of the biopsied blastocyst to recipients (Figure 4). Biopsies from embryos resulting in calf delivery showed enrichment of 52 differentially expressed transcripts involved in pathways associated with implantation, carbohydrate metabolism, growth factors and signal transduction. In contrast, biopsies of embryos that did not result in pregnancy showed enrichment of transcripts involved in inflammatory cytokines, protein amino acid binding, transcription factors and glucose metabolism. Using biopsies of in vivo-derived Day 7 blastocysts (Ghanem et al. 2011), our studies revealed a total of 41 genes that were differentially expressed between biopsies associated with no pregnancy and those associated with calf delivery. Biopsies that were associated with failure to establish a pregnancy showed enrichment of transcripts related to tumor necrosis factor, protein binding, RNA binding, calcium ion binding, and oxidoreductase activity; whereas, transcripts related to protein binding, DNA binding, structural component of ribosome, growth factor activity, and signal transducer activity were found to be highly expressed in biopsies associated with calf delivery. Genes involved in oxidoreductase activity, structural component of ribosome, ATPase inhibitor activity, protein binding, calcium ion binding, and nucleotide binding were up regulated in embryo biopsies resulting in resorption; whereas, biopsies resulting in calf delivery were enriched with transcripts regulating signal transducer activity, cell redox homeostasis, DNA binding, growth factor activity, and protein binding. Interestingly, there was little variation in the expression profile between samples that resulted in no pregnancy and those that ended

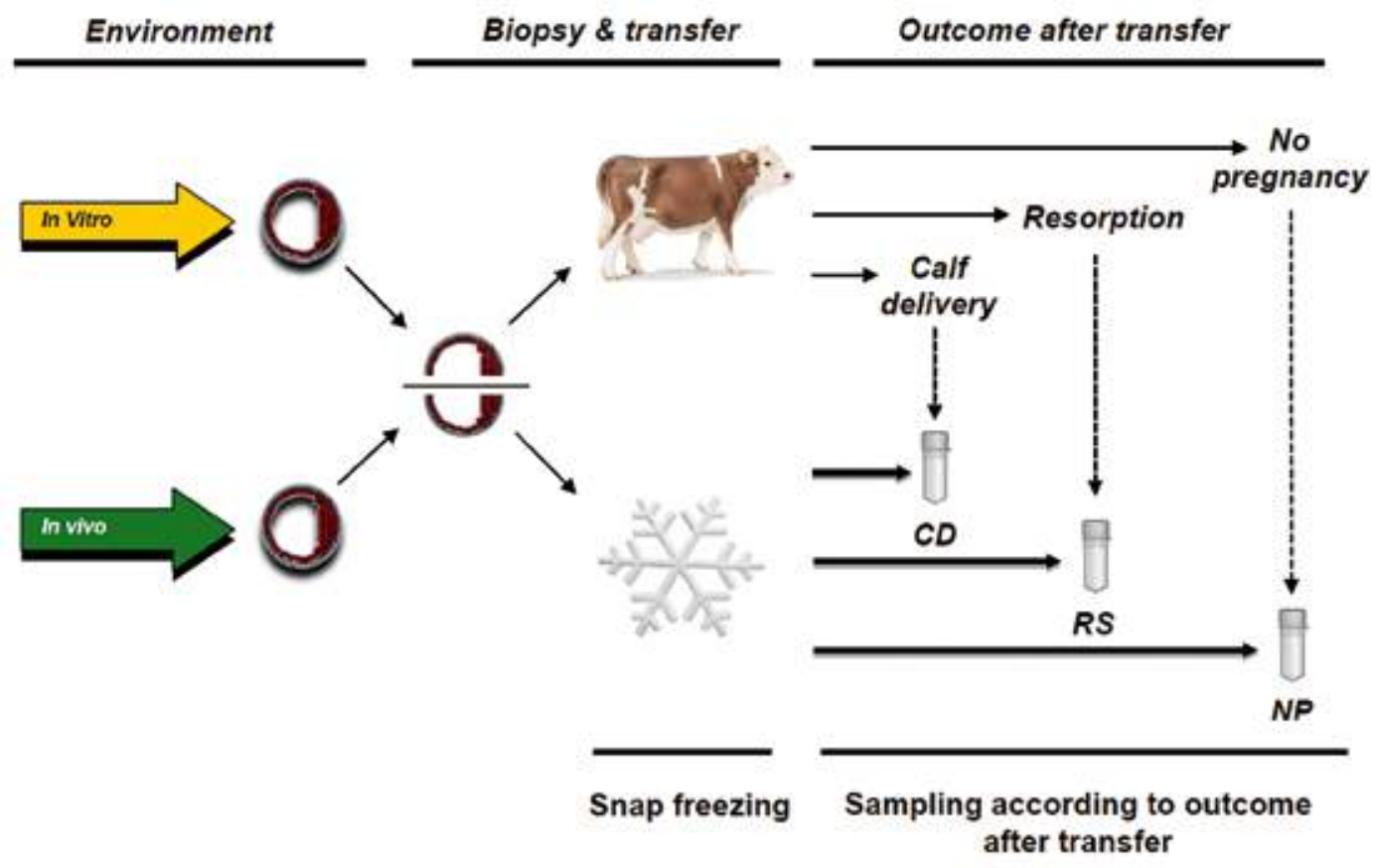

Figure 4. Overall experimental strategy to correlate blastocyst's molecular signature with its viability after transfer to recipient. To accomplish that, blastocysts (in vivo-derived and in vitro-derived) were split. One half was transferred to synchronized Simmental heifers followed by later pregnancy check, whereas the other proportion was immediately snap frozen. Later, frozen samples were categorized according to the pregnancy outcome of the transferred corresponding proportion, namely into Calf delivery (CD), initial pregnancy being terminated by day 42 termed Resorption (RP) and No pregnancy (NP), for global gene expression analysis (El-Sayed et al. 2006). 
up in resorption indicating high molecular similarity. Consequently, both sets of differentially expressed genes were combined to an aggregate signature of a blastocyst which failed to result in a calf. Importantly, comparison of this aggregate signature related to in vivo derived blastocysts with a similar signature derived from to in vitro derived embryos (El-Sayed et al. 2006) identified an overlap of 21 genes. Of these, 18 genes displayed an identical direction of expression (Table 1) and functional annotation analysis revealed involvement in biological functions related to protein binding \& synthesis, oxidative stress \& energy metabolism and mitochondrial function (Ghanem et al. 2011). Thus in vivo and in vitro derived blastocysts with term developmental competence share a similar molecular signature although derived from different environments.

\section{Conclusion}

With respect to endometrial receptivity, the present survey provides a comprehensive inventory of functional networks and genes expressed in the bovine endometrium representing the maternal part of the embryo-maternal cross-talk. Distinct molecular signatures of the bovine endometrium could be correlated with pregnancy success in the next ovulatory cycle. For

Table 1: Molecular signatures of bovine blastocysts related to pregnancy success

\begin{tabular}{|c|c|c|c|c|c|c|c|}
\hline \multirow[b]{2}{*}{ Genes } & \multirow[b]{2}{*}{ Gene function } & \multicolumn{3}{|c|}{ In vivo biopsies } & \multicolumn{3}{|c|}{ In vitro biopsies } \\
\hline & & $\begin{array}{c}\text { No } \\
\text { Pregnancy }\end{array}$ & Resorption & No Calf & No Calf & $\begin{array}{c}\text { No } \\
\text { Pregnancy }\end{array}$ & Resorption \\
\hline PTTG1 & Transcription factors & & $\uparrow$ & $\uparrow$ & $\uparrow$ & $\uparrow$ & \\
\hline KRT8 & Protein binding and synth. & $\downarrow$ & $\downarrow$ & $\downarrow$ & $\uparrow \downarrow$ & $\downarrow$ & $\uparrow$ \\
\hline RPLPO & Protein binding and synth. & $\downarrow$ & $\downarrow$ & $\downarrow$ & $\uparrow \downarrow$ & $\downarrow$ & $\uparrow$ \\
\hline$R P L 3$ & Protein binding and synth. & & $\uparrow$ & $\uparrow$ & $\uparrow$ & & $\uparrow$ \\
\hline RPS15A & Protein binding and synth. & & $\uparrow$ & $\uparrow$ & $\uparrow$ & & $\uparrow$ \\
\hline COQ7 & Protein binding and synth. & & $\downarrow$ & $\downarrow$ & $\uparrow$ & $\uparrow$ & $\uparrow$ \\
\hline EEF1A1 & Protein binding and synth. & $\uparrow$ & $\uparrow$ & $\uparrow$ & $\uparrow$ & $\uparrow$ & \\
\hline CD9 & Protein binding and synth. & & $\uparrow$ & $\uparrow$ & $\uparrow$ & $\uparrow$ & \\
\hline HSPD1 & Protein binding and synth. & $\uparrow$ & $\uparrow$ & $\uparrow$ & $\uparrow$ & & $\uparrow$ \\
\hline H2FAZ & DNA binding & $\downarrow$ & $\downarrow$ & $\downarrow$ & $\downarrow$ & & $\downarrow$ \\
\hline BMP15 & Growth factor & $\downarrow$ & $\downarrow$ & $\downarrow$ & $\downarrow$ & & $\downarrow$ \\
\hline S100A14 & Ion binding & $\uparrow$ & $\uparrow$ & $\uparrow$ & $\uparrow$ & $\uparrow$ & \\
\hline$T X N$ & Metabolism/Oxidative stress & & $\downarrow$ & $\downarrow$ & $\downarrow$ & $\downarrow$ & $\downarrow$ \\
\hline$A K R 1 B 1$ & Metabolism/Oxidative stress & $\uparrow$ & & $\uparrow$ & $\uparrow$ & $\uparrow$ & $\uparrow$ \\
\hline PGHS-2 & Metabolism/Oxidative stress & $\downarrow$ & $\downarrow$ & $\downarrow$ & $\downarrow$ & & $\downarrow$ \\
\hline PLAC8 & Tissue specific & & $\downarrow$ & $\downarrow$ & $\downarrow$ & & $\downarrow$ \\
\hline$T N F-\alpha$ & Immune response & $\uparrow$ & & $\uparrow$ & $\uparrow$ & $\uparrow$ & \\
\hline$F L 405$ & Mitochondrial transcripts & $\uparrow$ & $\uparrow$ & $\uparrow$ & $\uparrow$ & $\uparrow$ & \\
\hline Fl396 & Mitochondrial transcripts & & $\uparrow$ & $\uparrow$ & $\uparrow$ & & $\uparrow$ \\
\hline$N A D H$ & Mitochondrial transcripts & $\uparrow$ & & $\uparrow$ & $\uparrow$ & & $\uparrow$ \\
\hline$B 2 M$ & unknown & $\downarrow$ & & $\downarrow$ & $\downarrow$ & & $\downarrow$ \\
\hline
\end{tabular}

Up- $(\uparrow)$ and down-regulated $(\downarrow)$ genes in No pregnancy, Resorption and aggregate No Calf groups relative to calf delivery considering both in vivo- and in vitro-derived blastocysts

(El-Sayed et al. 2006, Ghanem et al. 2011) 
instance, molecular networks related to cell-to-cell communication, mitochondrial metabolic homoeostasis, tissue expansion as well as inflammatory immune mediators have been shown to contribute to improved receptivity and pregnancy success.

With respect to embryo quality, new strategies to connect molecular signatures with developmental capacities have been developed. Firstly, large scale differences at the molecular level were identified for blastomeres whose counterparts developed to the blastocyst stage compared to those with lower developmental competence thus unraveling distinct molecular fingerprints related to developmental potential. Secondly, molecular signatures of in vivo and in vitro derived blastocysts that were correlated with embryo developmental competence to term were identified, revealing a common genetic signature. Finally, further understanding of molecular networks related to embryo developmental capacity and endometrial receptivity has been gained from novel innovative strategies including endometrial samples as well as embryo microdissection and blastocyst biopsies.

\section{References}

Achache H \& Revel A 2006 Endometrial receptivity markers, the journey to successful embryo implantation. Hum Reprod Update 12 731-746.

Albelda SM \& Buck CA 1990 Integrins and other cell adhesion molecules. FASEB J 4 2868-2880.

Aplin JD 2000 The cell biological basis of human implantation. Baillieres Best Pract Res Clin Obstet Gynaecol 14 757764.

Austin CR 1951 Observations on the penetration of the sperm in the mammalian egg. Aust J Sci Res B 4 581-596.

Austin CR 1952 The capacitation of the mammalian sperm. Nature 170326.

Bauersachs S, Ulbrich SE, Gross K, Schmidt SE, Meyer HH, Wenigerkind H, Vermehren M, Sinowatz F, Blum H \& Wolf E 2006 Embryo-induced transcriptome changes in bovine endometrium reveal species-specific and common molecular markers of uterine receptivity. Reproduction 132 319-331.

Bauersachs S, Ulbrich SE, Zakhartchenko V, Minten M, Reichenbach M, Reichenbach HD, Blum H, Spencer TE \& Wolf E 2009 The endometrium responds differently to cloned versus fertilized embryos. Proc Natl Acad Sci U $S$ A 106 5681-5686.

Bazer FW, Spencer TE \& Ott TL 1997 Interferon tau: a novel pregnancy recognition signal. Am J Reprod Immunol 37 412-420.

Betsha S, Hoelker M, Salilew-Wondim D, Held E, Rings F, Grosse-Brinkhause C, Cinar MU, Havlicek V, Besenfelder U, Tholen E, Looft C, Schellander K \& Tesfaye D 2013 Transcriptome profile of bovine elongated conceptus obtained from SCNT and IVP pregnancies. Mol Reprod Dev 80 315-333.

Betts DH \& King WA 2001 Genetic regulation of embryo death and senescence. Theriogenology 55 171-191.

Boomsma CM, Kavelaars A, Eijkemans MJ, Lentjes EG, Fauser BC, Heijnen CJ \& Macklon NS 2009 Endometrial secretion analysis identifies a cytokine profile predictive of pregnancy in IVF. Hum Reprod 24 1427-1435.

Bowen JA \& Hunt JS 2000 The role of integrins in reproduction. Proc Soc Exp Biol Med 223 331-343.
Brambrink T, Wabnitz P, Halter R, Klocke R, Carnwath J, Kues W, Wrenzycki C, Paul D \& Niemann H 2002 Application of cDNA arrays to monitor mRNA profiles in single preimplantation mouse embryos. Biotechniques 33 376-378, 380, 382-375.

Brevini TA, Lonergan P, Cillo F, Francisci C, Favetta LA, Fair T \& Gandolfi F 2002 Evolution of mRNA polyadenylation between oocyte maturation and first embryonic cleavage in cattle and its relation with developmental competence. Mol Reprod Dev 63 510-517.

Carson DD, Bagchi I, Dey SK, Enders AC, Fazleabas AT, Lessey BA \& Yoshinaga K 2000 Embryo implantation. Dev Biol 223 217-237.

Chen DB, Hilsenrath R, Yang ZM, Le SP, Kim SR, Chuong CJ, Poindexter AN, 3rd \& Harper MJ 1995 Leukaemia inhibitory factor in human endometrium during the menstrual cycle: cellular origin and action on production of glandular epithelial cell prostaglandin in vitro. Hum Reprod 10 911-918.

Corcoran D, Rizos D, Fair T, Evans AC \& Lonergan P 2007 Temporal expression of transcripts related to embryo quality in bovine embryos cultured from the two-cell to blastocyst stage in vitro or in vivo. Mol Reprod Dev 74 972-977.

Cote I, Vigneault C, Laflamme I, Laquerre J, Fournier E, Gilbert I, Scantland S, Gagne D, Blondin P \& Robert C 2011 Comprehensive cross production system assessment of the impact of in vitro microenvironment on the expression of messengers and long non-coding RNAs in the bovine blastocyst. Reproduction 142 99-112.

Cross JC, Werb Z \& Fisher SJ 1994 Implantation and the placenta: key pieces of the development puzzle. Science 266 1508-1518.

Danielsson KG, Swahn ML \& Bygdeman M 1997 The effect of various doses of mifepristone on endometrial leukaemia inhibitory factor expression in the midluteal phase-an immunohistochemical study. Hum Reprod 12 1293-1297.

De Sousa PA, Westhusin ME \& Watson AJ 1998 Analysis of variation in relative $\mathrm{mRNA}$ abundance for specific gene 
transcripts in single bovine oocytes and early embryos. Mol Reprod Dev 49 119-130.

de Ziegler D, Fanchin R, de Moustier B \& Bulletti C 1998 The hormonal control of endometrial receptivity: estrogen (E2) and progesterone. J Reprod Immunol 39 149-166.

Dey SK, Lim H, Das SK, Reese J, Paria BC, Daikoku T \& Wang H 2004 Molecular cues to implantation. Endocr Rev 25 341-373.

Diskin MG, Murphy JJ \& Sreenan JM 2006 Embryo survival in dairy cows managed under pastoral conditions. Anim Reprod Sci 96 297-311.

Diskin MG \& Sreenan JM 1980 Fertilization and embryonic mortality rates in beef heifers after artificial insemination. J Reprod Fertil 59 463-468.

Dode MA, Dufort I, Massicotte L \& Sirard MA 2006 Quantitative expression of candidate genes for developmental competence in bovine two-cell embryos. Mol Reprod Dev 73 288-297.

Doherty AS, Mann MR, Tremblay KD, Bartolomei MS \& Schultz RM 2000 Differential effects of culture on imprinted $\mathrm{H} 19$ expression in the preimplantation mouse embryo. Biol Reprod 62 1526-1535.

Duranthon V, Watson AJ \& Lonergan P 2008 Preimplantation embryo programming: transcription, epigenetics, and culture environment. Reproduction 135 141-150.

Eckert J \& Niemann H 1998 mRNA expression of leukaemia inhibitory factor (LIF) and its receptor subunits glycoprotein 130 and LIF-receptor-beta in bovine embryos derived in vitro or in vivo. Mol Hum Reprod 4 957-965.

El-Sayed A, Hoelker M, Rings F, Salilew D, Jennen D, Tholen E, Sirard MA, Schellander K \& Tesfaye D 2006 Largescale transcriptional analysis of bovine embryo biopsies in relation to pregnancy success after transfer to recipients. Physiol Genomics 28 84-96.

Farin PW \& Farin CE 1995 Transfer of bovine embryos produced in vivo or in vitro: survival and fetal development. Biol Reprod 52 676-682.

Fazeli A, Affara NA, Hubank M \& Holt WV 2004 Sperminduced modification of the oviductal gene expression profile after natural insemination in mice. Biol Reprod 71 60-65.

Ferguson CE, Kesler DJ \& Godke RA 2011 Progesterone enhances in vitro development of bovine embryos. Theriogenology.

Forde N, Carter F, Fair T, Crowe MA, Evans AC, Spencer TE, Bazer FW, McBride R, Boland MP, O'Gaora P, Lonergan P \& Roche JF 2009a Progesterone-regulated changes in endometrial gene expression contribute to advanced conceptus development in cattle. Biol Reprod 81 784-794.

Forde N, Spencer TE, Bazer FW, Song G, Roche JF \& Lonergan P 2009b Effect of pregnancy and progesterone concentration on expression of genes encoding for transporters or secreted proteins in the bovine endometrium. Physiol Genomics 41 53-62.

Gad A, Hoelker M, Besenfelder U, Havlicek V, Cinar U, Rings F, Held E, Dufort I, Sirard MA, Schellander K \& Tesfaye D 2012 Molecular mechanisms and pathways involved in bovine embryonic genome activation and their regulation by alternative in vivo and in vitro culture conditions. Biol Reprod 87100.
Garrett JE, Geisert RD, Zavy MT, Gries LK, Wettemann RP \& Buchanan DS 1988 Effect of exogenous progesterone on prostaglandin F2 alpha release and the interestrous interval in the bovine. Prostaglandins 36 85-96.

Geisert RD, Fox TC, Morgan GL, Wells ME, Wettemann RP \& Zavy MT 1991 Survival of bovine embryos transferred to progesterone-treated asynchronous recipients. J Reprod Fertil 92 475-482.

Ghanem N, Salilew-Wondim D, Gad A, Tesfaye D, Phatsara C, Tholen E, Looft C, Schellander K \& Hoelker M 2011 Bovine blastocysts with developmental competence to term share similar expression of developmentally important genes although derived from different culture environments. Reproduction 142 551-564.

Ghosh D \& Sengupta J 2004 Endocrine and paracrine correlates of endometrial receptivity to blastocyst implantation in the human. Indian J Physiol Pharmacol 48 6-30.

Giudice LC 2004 Microarray expression profiling reveals candidate genes for human uterine receptivity. Am J Pharmacogenomics 4 299-312.

Glencross RG, Munro IB, Senior BE \& Pope GS 1973 Concentrations of oestradiol-17 beta, oestrone and progesterone in jugular venous plasma of cows during the oestrous cycle and in early pregnancy. Acta Endocrinol (Copenh) 73 374-384.

Gray CA, Burghardt RC, Johnson GA, Bazer FW \& Spencer TE 2002 Evidence that absence of endometrial gland secretions in uterine gland knockout ewes compromises conceptus survival and elongation. Reproduction 124 289-300.

Held E, Salilew-Wondim D, Linke M, Zechner U, Rings F, Tesfaye D, Schellander K \& Hoelker M 2012 Transcriptome fingerprint of bovine 2-cell stage blastomeres is directly correlated with the individual developmental competence of the corresponding sister blastomere. Biol Reprod 87154.

Henricks DM, Lamond DR, Hill JR \& Dickey JF 1971 Plasma progesterone concentrations before mating and in early pregnancy in the beef heifer. J Anim Sci 33 450-454.

Hoelker M, Rings F, Lund Q, Ghanem N, Phatsara C, Griese J, Schellander K \& Tesfaye D 2009 Effect of the microenvironment and embryo density on developmental characteristics and gene expression profile of bovine preimplantative embryos cultured in vitro. Reproduction 137 415-425.

Kato Y, Li X, Amarnath D, Ushizawa K, Hashizume K, Tokunaga T, Taniguchi M \& Tsunoda Y 2007 Comparative gene expression analysis of bovine nucleartransferred embryos with different developmental potential by cDNA microarray and real-time PCR to determine genes that might reflect calf normality. Cloning Stem Cells 9 495-511.

Kauma SW 2000 Cytokines in implantation. J Reprod Fertil Suppl 55 31-42.

Khosla S, Dean W, Brown D, Reik W \& Feil R 2001 Culture of preimplantation mouse embryos affects fetal development and the expression of imprinted genes. Biol Reprod 64 918-926.

Knijn HM, Wrenzycki C, Hendriksen PJ, Vos PL, Zeinstra EC, van der Weijden GC, Niemann H \& Dieleman SJ 2005 
In vitro and in vivo culture effects on mRNA expression of genes involved in metabolism and apoptosis in bovine embryos. Reprod Fertil Dev 17 775-784.

Krussel JS, Huang HY, Simon C, Behr B, Pape AR, Wen Y, Bielfeld P \& Polan ML 1998 Single blastomeres within human preimplantation embryos express different amounts of messenger ribonucleic acid for beta-actin and interleukin-1 receptor type I. J Clin Endocrinol Metab 83 953-959.

Lazzari G, Wrenzycki C, Herrmann D, Duchi R, Kruip T, Niemann H \& Galli C 2002 Cellular and molecular deviations in bovine in vitro-produced embryos are related to the large offspring syndrome. Biol Reprod $\mathbf{6 7}$ 767-775.

Ledee N, Dubanchet S, Oger P, Meynant C, Lombroso R, Ville Y \& Chaouat G 2007 Uterine receptivity and cytokines: new concepts and new applications. Gynecol Obstet Invest 64 138-143.

Ledee N, Munaut C, Aubert J, Serazin V, Rahmati M, Chaouat G, Sandra O \& Foidart JM 2011 Specific and extensive endometrial deregulation is present before conception in IVF/ICSI repeated implantation failures (IF) or recurrent miscarriages. J Pathol 225 554-564.

Lee KF, Chow JF, Xu JS, Chan ST, Ip SM \& Yeung WS 2001 A comparative study of gene expression in murine embryos developed in vivo, cultured in vitro, and cocultured with human oviductal cells using messenger ribonucleic acid differential display. Biol Reprod 64 910-917.

Lequarre AS, Grisart B, Moreau B, Schuurbiers N, Massip A \& Dessy F 1997 Glucose metabolism during bovine preimplantation development: analysis of gene expression in single oocytes and embryos. Mol Reprod Dev 48 216-226.

Lessey BA 1997 Integrins and the endometrium: new markers of uterine receptivity. Ann N Y Acad Sci 828 111-122.

Li HW, Liao SB, Chiu PC, Tam WW, Ho JC, Ng EH, Ho PC, Yeung WS, Tang F \& O WS 2010 Expression of adrenomedullin in human oviduct, its regulation by the hormonal cycle and contact with spermatozoa, and its effect on ciliary beat frequency of the oviductal epithelium. J Clin Endocrinol Metab 95 E18-25.

Li J \& Roberts RM 1994 Interferon-tau and interferon-alpha interact with the same receptors in bovine endometrium. Use of a readily iodinatable form of recombinant interferon-tau for binding studies. J Biol Chem 269 13544-13550.

Lim H, Song H, Paria BC, Reese J, Das SK \& Dey SK 2002 Molecules in blastocyst implantation: uterine and embryonic perspectives. Vitam Horm 64 43-76.

Liu AX, He WH, Yin LJ, Lv PP, Zhang Y, Sheng JZ, Leung PC \& Huang HF 2011 Sustained endoplasmic reticulum stress as a cofactor of oxidative stress in decidual cells from patients with early pregnancy loss. J Clin Endocrinol Metab 96 E493-497.

Lonergan P 2011 Influence of progesterone on oocyte quality and embryo development in cows. Theriogenology $\mathbf{7 6}$ 1594-1601.

Lonergan P, Fair T, Corcoran D \& Evans AC 2006 Effect of culture environment on gene expression and developmental characteristics in IVF-derived embryos. Theriogenology 65 137-152.
Lonergan P, Khatir H, Piumi F, Rieger D, Humblot P \& Boland MP 1999 Effect of time interval from insemination to first cleavage on the developmental characteristics, sex ratio and pregnancy rate after transfer of bovine embryos. J Reprod Fertil 117 159-167.

Loset M, Mundal SB, Johnson MP, Fenstad MH, Freed KA, Lian IA, Eide IP, Bjorge L, Blangero J, Moses EK \& Austgulen R 2011 A transcriptional profile of the decidua in preeclampsia. Am J Obstet Gynecol 204 84 e81-27.

Madaschi C, Aoki T, de Almeida Ferreira Braga DP, de Cassia Savio Figueira R, Semiao Francisco L, laconelli A, Jr. \& Borges E, Jr. 2009 Zona pellucida birefringence score and meiotic spindle visualization in relation to embryo development and ICSI outcomes. Reprod Biomed Online 18 681-686.

Mamo S, Carter F, Lonergan P, Leal CL, Al Naib A, McGettigan P, Mehta JP, Evans AC \& Fair T 2011 Sequential analysis of global gene expression profiles in immature and in vitro matured bovine oocytes: potential molecular markers of oocyte maturation. BMC Genomics 12151.

Mansouri-Attia N, Sandra O, Aubert J, Degrelle S, Everts RE, Giraud-Delville C, Heyman Y, Galio L, Hue I, Yang X, Tian XC, Lewin HA \& Renard JP 2009 Endometrium as an early sensor of in vitro embryo manipulation technologies. Proc Natl Acad Sci U S A 106 5687-5692.

Minami N, Sasaki K, Aizawa A, Miyamoto M \& Imai H 2001 Analysis of gene expression in mouse 2-cell embryos using fluorescein differential display: comparison of culture environments. Biol Reprod 64 30-35.

Naivar KA, Ward SK, Austin KJ, Moore DW \& Hansen TR 1995 Secretion of bovine uterine proteins in response to type I interferons. Biol Reprod 52 848-854.

Norwitz ER, Schust DJ \& Fisher SJ 2001 Implantation and the survival of early pregnancy. N Engl J Med 345 1400-1408.

Numabe T, Oikawa T, Kikuchi T \& Horiuchi T 2000 Production efficiency of Japanese black calves by transfer of bovine embryos produced in vitro. Theriogenology 54 1409-1420.

Paria BC, Lim H, Das SK, Reese J \& Dey SK 2000 Molecular signaling in uterine receptivity for implantation. Semin Cell Dev Biol 11 67-76.

Paria BC, Reese J, Das SK \& Dey SK 2002 Deciphering the cross-talk of implantation: advances and challenges. Science 296 2185-2188.

Paria BC, Song H \& Dey SK 2001 Implantation: molecular basis of embryo-uterine dialogue. Int J Dev Biol 45 597-605.

Ponsuksili S, Murani E, Schwerin M, Schellander K, Tesfaye D \& Wimmers K 2012 Gene expression and DNA-methylation of bovine pretransfer endometrium depending on its receptivity after in vitro-produced embryo transfer. PLoS One 7 e42402.

Reese J, Das SK, Paria BC, Lim H, Song H, Matsumoto H, Knudtson KL, DuBois RN \& Dey SK 2001 Global gene expression analysis to identify molecular markers of uterine receptivity and embryo implantation. J Biol Chem 276 44137-44145.

Revel A, Helman A, Koler M, Shushan A, Goldshmidt O, Zcharia E, Aingorn H \& Vlodavsky I 2005 Heparanase 
improves mouse embryo implantation. Fertil Steril $\mathbf{8 3}$ 580-586.

Rief S, Sinowatz F, Stojkovic M, Einspanier R, Wolf E \& Prelle K 2002 Effects of a novel co-culture system on development, metabolism and gene expression of bovine embryos produced in vitro. Reproduction 124 543-556.

Riesewijk A, Martin J, van Os R, Horcajadas JA, Polman J, Pellicer A, Mosselman S \& Simon C 2003 Gene expression profiling of human endometrial receptivity on days $\mathrm{LH}+2$ versus $\mathrm{LH}+7$ by microarray technology. Mol Hum Reprod 9 253-264.

Rizos D, Carter F, Besenfelder U, Havlicek V \& Lonergan P 2010 Contribution of the female reproductive tract to low fertility in postpartum lactating dairy cows. J Dairy Sci 93 1022-1029.

Rizos D, Gutierrez-Adan A, Perez-Garnelo S, De La Fuente J, Boland MP \& Lonergan P 2003 Bovine embryo culture in the presence or absence of serum: implications for blastocyst development, cryotolerance, and messenger RNA expression. Biol Reprod 68 236-243.

Rizos D, Lonergan P, Boland MP, Arroyo-Garcia R, Pintado B, de la Fuente J \& Gutierrez-Adan A 2002a Analysis of differential messenger RNA expression between bovine blastocysts produced in different culture systems: implications for blastocyst quality. Biol Reprod 66 589595.

Rizos D, Ward F, Duffy P, Boland MP \& Lonergan P 2002b Consequences of bovine oocyte maturation, fertilization or early embryo development in vitro versus in vivo: implications for blastocyst yield and blastocyst quality. Mol Reprod Dev 61 234-248.

Saino M, Maruyama T, Sekiya T, Kayama T \& Murakami Y 2004 Inhibition of angiogenesis in human glioma cell lines by antisense RNA from the soluble guanylate cyclase genes, GUCY1A3 and GUCY1B3. Oncol Rep 12 47-52.

Salamonsen LA, Dimitriadis E \& Robb L 2000 Cytokines in implantation. Semin Reprod Med 18 299-310.

Salamonsen LA, Hannan NJ \& Dimitriadis E 2007 Cytokines and chemokines during human embryo implantation: roles in implantation and early placentation. Semin Reprod Med 25 437-444.

Salilew-Wondim D, Holker M, Rings F, Ghanem N, UlasCinar M, Peippo J, Tholen E, Looft C, Schellander K \& Tesfaye D 2010 Bovine pretransfer endometrium and embryo transcriptome fingerprints as predictors of pregnancy success after embryo transfer. Physiol Genomics 42 201-218.

Salilew-Wondim D, Tesfaye D, Hossain M, Held E, Rings F, Tholen E, Looft C, Cinar U, Schellander K \& Hoelker M 2013 Aberrant placenta gene expression pattern in bovine pregnancies established after transfer of cloned or in vitro produced embryos. Physiol Genomics 45 28-46.

Satterfield MC, Song G, Hayashi K, Bazer FW \& Spencer TE 2008 Progesterone regulation of the endometrial WNT system in the ovine uterus. Reprod Fertil Dev 20 935-946.

Savouret JF, Misrahi M \& Milgrom E 1990 Molecular action of progesterone. Int J Biochem 22 579-594.

Smith SL, Everts RE, Tian XC, Du F, Sung LY, RodriguezZas SL, Jeong BS, Renard JP, Lewin HA \& Yang X 2005 Global gene expression profiles reveal significant nuclear reprogramming by the blastocyst stage after cloning. Proc Natl Acad Sci U S A 102 17582-17587.

Song H, Lim H, Das SK, Paria BC \& Dey SK 2000 Dysregulation of EGF family of growth factors and COX-2 in the uterus during the preattachment and attachment reactions of the blastocyst with the luminal epithelium correlates with implantation failure in LIF-deficient mice. Mol Endocrinol 14 1147-1161.

Spencer TE \& Bazer FW 2002 Biology of progesterone action during pregnancy recognition and maintenance of pregnancy. Front Biosci 7 d1879-1898.

Spencer TE, Johnson GA, Bazer FW, Burghardt RC \& Palmarini M 2007 Pregnancy recognition and conceptus implantation in domestic ruminants: roles of progesterone, interferons and endogenous retroviruses. Reprod Fertil Dev 19 65-78.

Spencer TE, Ott TL \& Bazer FW 1996 tau-Interferon: pregnancy recognition signal in ruminants. Proc Soc Exp Biol Med 213 215-229.

Spencer TE, Sandra O \& Wolf E 2008 Genes involved in conceptus-endometrial interactions in ruminants: insights from reductionism and thoughts on holistic approaches. Reproduction 135 165-179.

Spencer TE, Stagg AG, Joyce MM, Jenster G, Wood CG, Bazer FW, Wiley AA \& Bartol FF 1999 Discovery and characterization of endometrial epithelial messenger ribonucleic acids using the ovine uterine gland knockout model. Endocrinology 140 4070-4080.

Stewart CL, Kaspar P, Brunet LJ, Bhatt H, Gadi I, Kontgen F \& Abbondanzo SJ 1992 Blastocyst implantation depends on maternal expression of leukaemia inhibitory factor. Nature 359 76-79.

Stolk L, Perry JR, Chasman DI, He C, Mangino M et al. 2012 Meta-analyses identify 13 loci associated with age at menopause and highlight DNA repair and immune pathways. Nat Genet 44 260-268.

Sugino N, Kashida S, Karube-Harada A, Takiguchi S \& Kato H 2002 Expression of vascular endothelial growth factor (VEGF) and its receptors in human endometrium throughout the menstrual cycle and in early pregnancy. Reproduction 123 379-387.

Suzuki T, Schirra F, Richards SM, Jensen RV \& Sullivan DA 2008 Estrogen and progesterone control of gene expression in the mouse meibomian gland. Invest Ophthalmol Vis Sci 49 1797-1808.

Tabibzadeh S 1998 Molecular control of the implantation window. Hum Reprod Update 4 465-471.

Tabibzadeh S \& Babaknia A 1995 The signals and molecular pathways involved in implantation, a symbiotic interaction between blastocyst and endometrium involving adhesion and tissue invasion. Hum Reprod 10 1579-1602.

Tapia A, Salamonsen LA, Manuelpillai U \& Dimitriadis E 2008 Leukemia inhibitory factor promotes human first trimester extravillous trophoblast adhesion to extracellular matrix and secretion of tissue inhibitor of metalloproteinases-1 and -2. Hum Reprod 23 1724-1732.

Thomas K, Thomson AJ, Wood SJ, Kingsland CR, Vince G \& Lewis-Jones DI 2003 Endometrial integrin expression in women undergoing IVF and ICSI: a comparison of the 
two groups and fertile controls. Hum Reprod 18 364-369.

van Mourik MS, Macklon NS \& Heijnen CJ 2009 Embryonic implantation: cytokines, adhesion molecules, and immune cells in establishing an implantation environment. J Leukoc Biol 85 4-19.

Wang H \& Dey SK 2006 Roadmap to embryo implantation: clues from mouse models. Nat Rev Genet 7 185-199.

Wrenzycki C, Herrmann D, Carnwath JW \& Niemann H 1996 Expression of the gap junction gene connexin43 (Cx43) in preimplantation bovine embryos derived in vitro or in vivo. J Reprod Fertil 108 17-24.

Wrenzycki C, Herrmann D, Carnwath JW \& Niemann H 1999 Alterations in the relative abundance of gene transcripts in preimplantation bovine embryos cultured in medium supplemented with either serum or PVA. Mol Reprod Dev 53 8-18.
Wrenzycki C, Herrmann D, Keskintepe L, Martins A, Jr., Sirisathien S, Brackett B \& Niemann H 2001 Effects of culture system and protein supplementation on mRNA expression in pre-implantation bovine embryos. Hum Reprod 16 893-901.

Wrenzycki C, Herrmann D, Lucas-Hahn A, Korsawe K, Lemme E \& Niemann H 2005 Messenger RNA expression patterns in bovine embryos derived from in vitro procedures and their implications for development. Reprod Fertil Dev 17 23-35.

Wrenzycki C, Herrmann D \& Niemann H 2007 Messenger RNA in oocytes and embryos in relation to embryo viability. Theriogenology 68 Suppl 1 S77-83. 
